REVIEW

MECHANISMS IN ENDOCRINOLOGY

\title{
Notch signaling in skeletal health and disease
}

Stefano Zanotti and Ernesto Canalis

Department of Research, Saint Francis Hospital and Medical Center, 114 Woodland Street, Hartford, Connecticut 06105-1299, USA and School of Medicine, The University of Connecticut, Farmington, Connecticut 06030, USA

(Correspondence should be addressed to E Canalis at Department of Research, Saint Francis Hospital and Medical Center;

Email: ecanalis@stfranciscare.org)

\begin{abstract}
Notch receptors are single-pass transmembrane proteins that determine cell fate. Upon Notch ligand interactions, proteolytic cleavages release the Notch intracellular domain, which translocates to the nucleus to regulate the transcription of target genes, including Hairy enhancer of split (Hes) and Hes related to YRPW motif (Hey). Notch is critical for skeletal development and activity of skeletal cells, and dysregulation of Notch signaling is associated with human diseases affecting the skeleton. Inherited or sporadic mutations in components of the Notch signaling pathway are associated with spondylocostal dysostosis, spondylothoracic dysostosis and recessive brachydactyly, diseases characterized by skeletal patterning defects. Inactivating mutations of the Notch ligand JAG1 or of NOTCH2 are associated with Alagille syndrome, and activating mutations in NOTCH2 are associated with Hajdu-Cheney syndrome (HCS). Individuals affected by HCS exhibit osteolysis in distal phalanges and osteoporosis. NOTCH is activated in selected tumors, such as osteosarcoma, and in breast cancer cells that form osteolytic bone metastases. In conclusion, Notch regulates skeletal development and bone remodeling, and gain- or loss-of-function mutations of Notch signaling result in important skeletal diseases.
\end{abstract}

European Journal of Endocrinology 168 R95-R103

\section{Skeletal cells and bone remodeling}

Skeletal tissue arises from distinct developmental processes. Cells of the cranial neural crest form the bones of the craniofacial skeleton, whereas the axial skeleton develops from somites $(1,2)$. Hyaline cartilage templates of appendicular bones originate from the proliferation and chondrogenic differentiation of mesenchymal cells residing in the limb bud. Chondrocytes in hyaline cartilage proliferate and acquire a hypertrophic phenotype, deposit a mineralized matrix, and ultimately become apoptotic. These events result in the formation of a calcified cartilage scaffold, which is vascularized and subsequently colonized by skeletal cell precursors that will replace cartilage with bone (3). Osteoblasts derive from mesenchymal cells that reside in the bone marrow and are the bone forming cells, which can differentiate further into lining cells or into osteocytes or can die by apoptosis $(4,5,6)$. Osteocytes are terminally differentiated cells embedded in the mineralized matrix $(7,8)$. Osteoclasts, multinucleated cells that arise from the fusion of mononuclear precursors of the hematopoietic lineage, are the bone resorbing cells. Their formation requires receptor activator of nuclear factor $\kappa \mathrm{B}$ ligand (RANKL) (9) and macrophage colony stimulating factor, whereas osteoprotegerin is a soluble inhibitor of RANKL. Therefore, the balance of RANKL and osteoprotegerin regulates osteoclastogenesis (9). Osteoblasts and osteoclasts play a critical role in the modeling of the growing skeleton, and the coupled function of these cells controls the remodeling of skeletal tissue throughout life (10).

The differentiation and function of cells of the osteoblastic and osteoclastic lineages are regulated by systemic and local signals, and the balance of their activities is essential to maintain bone remodeling. Notch has emerged recently as a local signal that plays a critical role in skeletal development, osteoblastic cell fate and function, and osteoclastogenesis (11). Consequently, it is not a surprise that gain- and lossof-function mutations of various components of the Notch signaling pathway result in a variety of skeletal disorders. Furthermore, alterations in Notch signaling have been associated with selected malignancies and their skeletal metastatic potential (12).

\section{Notch signaling in skeletal development and bone remodeling}

Notch is a family of four (Notch 1-4) transmembrane receptors activated by Notch ligand interactions 
$(11,13,14,15)$. Classical or canonical Notch ligands are the single-pass membrane proteins Jagged 1 and 2 and delta-like (DII) 1, 3, and 4. Following Notch ligand binding, the $\gamma$-secretase complex, containing the Presenilin 1 and 2 proteases, cleaves the transmembrane domain of Notch, allowing the release and ultimate nuclear translocation of the Notch intracellular domain (NICD). In the nucleus, NICD interacts with the DNA-binding protein CSL (for Epstein-Barr virus latency $\mathrm{C}$ promoter-binding factor 1 , suppressor of Hairless and Lag1), also known as Rbpjk. This leads to the assembly of the transcriptional complex formed by NICD, CSL/Rbpjk, and Mastermind-like (Maml), and the subsequent displacement of transcriptional repressors and the induction of Notch target genes (Fig. 1) (15). Hairy enhancer of split (Hes) and Hes-related with YRPW motif (Hey) are classical targets of Notch signaling (14). The C-terminus of Notch contains a proline (P)-, glutamic acid (E)-, serine (S)-, and threonine (T)-rich (PEST) domain, which is necessary for the ubiquitinylation and subsequent degradation of the Notch protein in the proteasome, ensuring proper duration of the Notch signal $(13,15)$.

Notch signaling determines the segmentation of the axial skeleton during somitogenesis $(16,17)$, and its induction in the limb bud suppresses chondrogenesis, an effect that appears to be mediated by Hes $1(18,19$, $20,21)$. The role played by Notch in mature chondrocytes is less clear $(22,23,24,25)$. Notch signaling regulates osteoblast and osteoclast differentiation and function and as a consequence controls bone remodeling. The effects of Notch in cells of the osteoblastic lineage are cell-context dependent and determined by the degree of differentiation of the cells targeted by Notch. Notch suppresses progression to a mature osteoblastic phenotype and osteoblast function, when expressed during the early stages of the osteoblastic differentiation program, leading to suppressed bone formation and bone loss (19, 26, 27, 28, 29). Notch inhibits osteoclast formation and bone resorption by inducing osteoprotegerin expression in osteoblasts $(26,30)$. Accordingly, NICD overexpression in mature osteoblasts and osteocytes increases trabecular bone mass due to suppressed osteoclast formation and bone resorption (29). Most of the studies reported have examined the function of Notch1, so that less is known regarding the function of Notch2, 3, and 4 in the skeleton. There is evidence that Notch 1 and 2 have distinct activities. For example, activation of Notch1 in osteoclast precursors prevents their differentiation toward mature osteoclasts, whereas activation of Notch2 enhances osteoclastogenesis $(31,32)$.

\section{Developmental skeletal diseases associated with Notch signaling}

\section{Dysostoses of the axial skeleton}

Spondylocostal dysostosis and spondylothoracic dysostosis are forms of trunk dwarfism caused by congenital abnormalities of the vertebrae and ribs secondary to defective somitogenesis (Table 1). Mutations of the various components of the Notch signaling pathway are associated with the diseases, and autosomal recessive inheritance is observed most frequently, although cases of autosomal dominant transmission have been reported $(33,34,35)$. The phenotypes of delta-like 3 (Dll3) null mice recapitulate the manifestations of spondylocostal dysostosis, and mutations in DLL3, leading to the translation of a truncated or misfolded protein of this Notch ligand, are found in humans affected by the disease $(36,37,38,39)$. Mesoderm

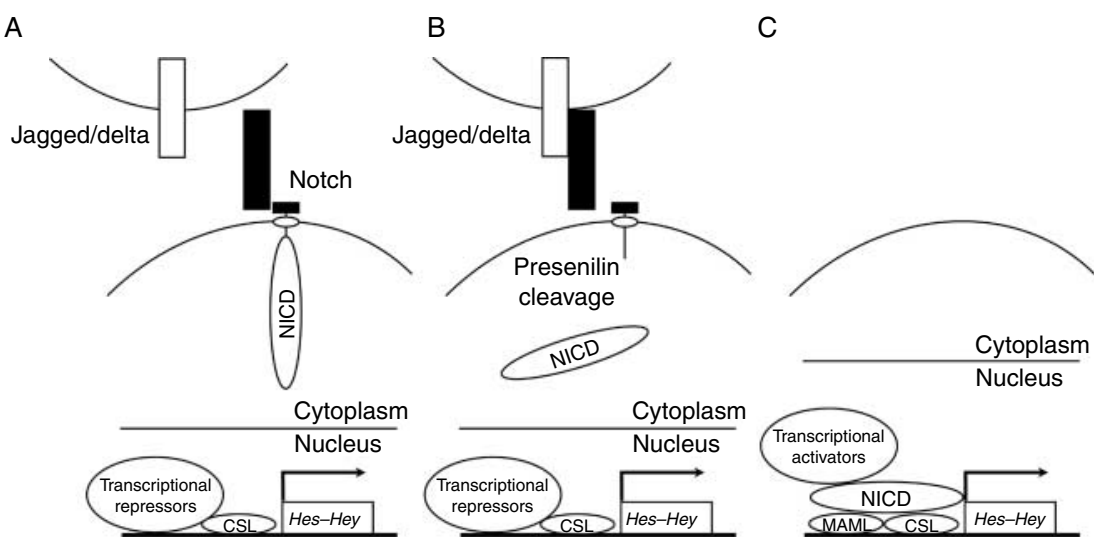

Figure 1 Activation of Notch signaling. (A) Notch receptors and Jagged/delta ligands are expressed as single-pass transmembrane proteins. Epstein-Barr virus latency C promoter-binding factor 1, suppressor of hairless, Lag1 (CSL), also termed Rbpjk, is bound to DNA and inhibits gene expression by recruiting transcriptional repressors. (B) Receptor-ligand interactions lead to the cleavage of the Notch receptor mediated by Presenilin and release of the Notch intracellular domain (NICD) to the cytoplasm. (C) NICD translocates to the nucleus and forms a ternary complex with CSL and Mastermind-like (MAML), replacing transcriptional repressors with transcriptional activators and inducing expression of Notch target genes, such as Hairy enhancer of split (Hes) and Hes-related with YRPW motif (Hey). 
Table 1 Skeletal diseases associated with Notch mutations.

\begin{tabular}{|c|c|c|c|}
\hline Disease & Mutated gene & Major manifestations & $\begin{array}{l}\text { Possibly impaired Notch } \\
\text { function }\end{array}$ \\
\hline Spondylocostal dysostoses & DLL3, MESP2, HES7, LFNG & $\begin{array}{l}\text { Dwarfism } \\
\text { Vertebral developmental defects }\end{array}$ & $\begin{array}{l}\text { Regulation of the segmentation } \\
\text { clock during somitogenesis }\end{array}$ \\
\hline Spondylothoracic dysostoses & MESP2 & $\begin{array}{l}\text { Dwarfism } \\
\text { Vertebral developmental defects }\end{array}$ & \\
\hline Brachydactyly & CHYS1 & $\begin{array}{l}\text { Short digits } \\
\text { Stunted growth }\end{array}$ & $\begin{array}{l}\text { Patterning of the digits during } \\
\text { development }\end{array}$ \\
\hline Alagille syndrome $e^{a}$ & JAG1, NOTCH2 & $\begin{array}{l}\text { Facial dysmorphism } \\
\text { Vertebral abnormalities } \\
\text { Bile duct atresia } \\
\text { Cardiovascular defects }\end{array}$ & $\begin{array}{l}\text { Craniofacial development; } \\
\text { regulation of the segmentation } \\
\text { clock during somitogenesis; } \\
\text { vascular development }\end{array}$ \\
\hline Hajdu-Cheney syndrome ${ }^{a}$ & NOTCH2 & $\begin{array}{l}\text { Acro-osteolysis } \\
\text { Osteoporosis } \\
\text { Fibular deformities } \\
\text { Polycystic kidneys }\end{array}$ & Unknown \\
\hline
\end{tabular}

DLL3, delta-like 3; MESP2, mesoderm posterior 2; HES7, Hairy and enhancer of split 7; LFNG, lunatic fringe; CHSY1, chondroitin sulfate synthase 1; JAG1, Jagged 1.

${ }^{a}$ Additional details are outlined in Tables 2 and 3.

posterior 2 (Mesp2) is a Notch target gene, which encodes a transcription factor critical for somitogenesis, and Mesp 2 null mice exhibit vertebral defects $(17,40)$. Accordingly, individuals that display abnormal segmentation of the thoracic vertebrae, typical of spondylocostal dysostosis, harbor homozygous nonsense mutations of MESP2 (41). Similarly, spondylothoracic dysostosis, which is observed mostly in people of Puerto Rican descent, is associated with a mutant MESP2 allele (42). Hes7 regulates the transcription of lunatic fringe (Lfng), which, by regulating the glycosylation of Notch, changes the affinity of Notch receptors for its ligands (43). Inactivation of $\mathrm{Lfng}$ or Hes 7 in mice leads to abnormal development of the rib cage and vertebral column, and mutations in LFNG and HES7 are associated with spondylocostal dysostosis in humans $(44,45,46,47,48,49)$.

\section{Brachydactyly}

Brachydactyly is characterized by shortening of the digits of the hands and feet (50). In mice, the global inactivation of the Notch ligand Jag2 causes digit abnormalities and defects of the craniofacial skeleton that lead to perinatal death, indicating that perturbations of Notch signaling result in developmental defects that are reminiscent of brachydactyly $(51,52)$. A null allele of chondroitin sulfate synthase 1 (CHSY1) was discovered in members of a Jordanian family diagnosed with a syndromic form of brachydactyly that presented with stunted growth, micrognathia, and learning disabilities. CHSY 1 encodes a transmembrane protein containing a fringe domain, and cultured fibroblasts from affected individuals exhibited Notch activation secondary to upregulation of the ligand encoded by JAG1. Recombinant CHSY1 inhibited Notch signaling in vitro, indicating that excessive activation of
Notch signaling is responsible for the disease (53). Chsy1 null mice display abnormalities in digit patterning, although the phenotype appears to be secondary to dysregulation of Indian hedgehog and transforming growth factor $\beta$ (TGF $\beta$ ) and not of Notch signaling (54).

\section{Alagille syndrome}

Alagille syndrome is an autosomal dominant disease that presents with cardiovascular defects, abnormalities of the craniofacial skeleton and vertebral column, cholestatic liver disease due to impaired formation of bile ducts, and renal anomalies, including dysplasia (Table 2) (55). In individuals affected by Alagille syndrome, vertebrae fail to fuse ventrally during development and assume a characteristic 'butterfly' appearance in radiographic images (56). Osteoporosis possibly secondary to liver failure and malnutrition has been reported in patients with the disease. Alagille syndrome is associated with mutations of JAG1, and these are mostly de novo mutations that lead to the translation of a truncated JAG1 protein, although complete gene deletions and missense mutations are also observed $(57,58,59)$. Rarely, mutations of

Table 2 Features of Alagille syndrome.

\begin{tabular}{|c|c|c|}
\hline $\begin{array}{l}\text { Craniofacial } \\
\text { features }\end{array}$ & Skeletal features & Other features \\
\hline Broad nasal bridge & Butterfly vertebrae & Bile duct atresia \\
\hline Craniosynostosis & Digit abnormalities & Cholestatic liver failure \\
\hline Deep set eyes & Osteoporosis & Cardiovascular \\
\hline Micrognathia & secondary to & defects, including \\
\hline Pointed chin & liver failure & Tetralogy of Fallot \\
\hline Prominent forehead & Short stature & Intracranial bleeding \\
\hline Triangular facies & & Renal failure \\
\hline
\end{tabular}


Table 3 Features of Hajdu-Cheney syndrome.

\begin{tabular}{lll}
\hline $\begin{array}{l}\text { Craniofacial } \\
\text { features }\end{array}$ & $\begin{array}{l}\text { Skeletal } \\
\text { features }\end{array}$ & Other features \\
\hline $\begin{array}{l}\text { Facial dysmorphism } \\
\text { Microretrognathism }\end{array}$ & $\begin{array}{l}\text { Acro-osteolysis } \\
\text { Fibular deformities }\end{array}$ & $\begin{array}{l}\text { Cardiovascular defects } \\
\text { Developmental delay }\end{array}$ \\
$\begin{array}{l}\text { Periodontal disease } \\
\text { Platysbasia }\end{array}$ & $\begin{array}{l}\text { Joint hyperlaxity } \\
\text { Osteoporosis } \\
\text { With fractures }\end{array}$ & $\begin{array}{l}\text { Hearing loss } \\
\text { Neurological symptoms } \\
\text { Polycystic kidneys }\end{array}$ \\
$\begin{array}{l}\text { Tooth loss } \\
\text { Wormian bones }\end{array}$ & Short stature & \\
\hline
\end{tabular}

NOTCH2 have been found to be associated with Alagille syndrome, either in isolation or in addition to mutations of JAG1 $(60,61)$. Global Jag1 null mice die during development, and the dual heterozygous inactivation of Jag1 and Notch 2 in mice recapitulates most of the defects found in Alagille syndrome, confirming that the disease is secondary to mutations of these genes (62). In addition, inactivation of Jag1 selectively in cells of the cranial neural crest phenocopies the abnormalities of the craniofacial skeleton that characterize Alagille syndrome, confirming its association with impaired Notch signaling (63).

\section{Gain-of-function mutations of Notch signaling}

\section{Hajdu-Cheney syndrome}

Hajdu-Cheney syndrome (HCS) is a devastating disease characterized by focal bone lysis of distal phalanges and by generalized osteoporosis $(64,65,66,67,68)$. The disease was first described in 1948 in a 37-year-old accountant who died 12 years later, and the syndrome was reported by Cheney (1965) (Table 3) $(64,65)$. HCS is transmitted as an autosomal dominant disease, although many sporadic cases occur. Over 60 years after the original description, whole exome sequencing in individuals affected with HCS revealed the presence of point mutations in exon 34 of NOTCH2 leading to the creation of a stop codon and the premature termination of the protein product upstream of the PEST domain $(69,70,71)$. It is of interest that NOTCH2 transcript levels were equivalent to those observed in controls, indicating a reduced capacity to activate the process of nonsense-mediated mRNA decay. As the PEST domain contains sequences necessary for the ubiquitinylation and degradation of Notch in the proteasome, the mutations lead to a stable protein and persistence of NOTCH2 signaling as all sequences required for the formation of the Notch transcriptional complex are upstream of the PEST domain and are therefore preserved (Fig. 2).

Despite the pronounced skeletal abnormalities reported in HCS, little is known regarding the mechanisms underlying the bone loss. Although the distal phalangeal osteolytic lesions would suggest increased localized bone resorption, there is no information on the mechanisms responsible for the generalized osteoporosis. The focal osteolysis is accompanied by neovascularization, inflammation, and fibrosis $(72,73,74)$. Iliac crest biopsies have been reported in a small number of cases of HCS and revealed decreased trabecular bone, normal or increased bone remodeling, and normal or decreased bone formation $(73,75,76,77)$. Whether the osteoblast/osteocyte or the osteoclast is the cell responsible for the presumed change in bone turnover has not been established. In osteoclast precursors, Notch2 induces nuclear factor of T-cells 1 transcription and osteoclastogenesis (32). This effect is exclusively observed with Notch2 and not with Notch1, but whether this mechanism operates in HCS is not known.

Bisphosphonate therapy (alendronate and pamidronate) alone or in combination with anabolic therapy with teriparatide has been attempted for the treatment of the skeletal manifestations of patients with HCS, but there is no clear evidence that either therapy is beneficial $(77,78,79)$. Serpentine fibula-polycystic kidney syndrome appears to be the same disease as HCS, and missense mutations in exon 34 of NOTCH2, upstream of sequences encoding for the PEST domain, were detected in patients affected by this disease $(68,80,81)$. Although HCS affects a limited number of individuals, discovering a cluster of mutations in a single domain of NOTCH2 in patients with HCS sheds light on potential mechanisms underpinning the development of osteoporosis. Multiple attempts to uncover genetic variants that contribute to the risk of osteoporosis have been

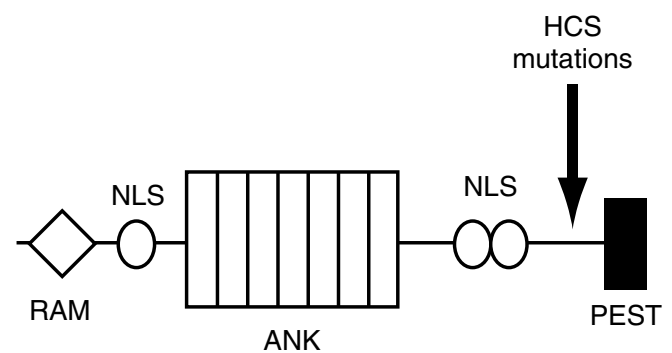

Figure 2 Structure of the NOTCH2 intracellular domain and mutations associated with Hajdu-Cheney syndrome. The intracellular domain of NOTCH2 (NICD) consists of a transcriptional domain formed by an Rbpjk association module (RAM) linked to ankyrin (ANK) repeats and a nuclear localization sequence (NLS). The C-terminus contains the proline $(P)$-, glutamic acid $(E)-$, serine (S)-, and threonine (T)-rich motif (PEST) domain, which is required for the ubiquitinylation and degradation of the NICD. Nonsense mutations in exon 34 associated with Hajdu-Cheney syndrome (HCS) and pointed by the arrow lead to the formation of a truncated protein consisting of all NOTCH2 sequences necessary for the formation of the transcriptional complex, but lacking the PEST domain needed for the ubiquitinylation and degradation of NOTCH2. As such, a stable and active NOTCH2 protein is synthesized. 
relatively unsuccessful $(82,83)$. However, bone mineral density and risk of osteoporotic fractures were associated with a select JAG1 allele in seven independent cohorts of women of Asian and European descent (84).

\section{Notch and skeletal malignancies}

Malignancies arising from cells of the hematopoietic lineage, such as T-cell leukemia, can exhibit activating mutations of NOTCH1 and dysregulated Notch signaling, which may cause uncontrolled cell proliferation and inhibit apoptosis (85). Human osteosarcoma cells exhibit greater expression of the Notch ligand JAG1, of NOTCH1, and of the Notch target gene HES1 than normal human osteoblasts, and the ability of osteosarcoma cells to metastasize correlates with increased Notch signaling $(86,87)$. Tumor burden in mice inoculated with human osteosarcoma cell lines was alleviated when cells expressing a dominant negative form of MAML, which inhibits Notch signaling, were used, or when $\gamma$-secretase inhibitors, to prevent Notch activation, were administered systemically (86). In addition, inhibition of $\gamma$-secretase prevented the growth of human osteosarcoma cells implanted subcutaneously in immunodeficient mice, confirming that activation of Notch signaling plays a critical role in the development of osteosarcoma (88).

Co-culture of human bone marrow stromal cells with cells from carcinoma of the breast induces NOTCH3 expression in the tumor cells, although the mechanisms mediating the effect are not known (89). Carcinoma of the breast cells induces osteolytic bone metastases in immunodeficient mice, and downregulation of NOTCH3 opposes this effect, suggesting a role for NOTCH3 in tumor invasion (89). Expression of JAG1 in human breast cancer cells is associated with increased tumor burden and the ability of the tumor cells to metastasize to bone when implanted in immunodeficient mice. In this experimental model, JAG1 expressing tumor cells stimulated osteoblasts to secrete interleukin 6 , which in turn induced the maturation of osteoclast precursors and the formation of osteolytic metastases. This led to the degradation of the extracellular matrix surrounding the lytic lesions, and the release of TGF $\beta$, which promoted JAG1 expression by tumor cells, creating a positive feedback loop favoring tumor invasion (90). In agreement with these findings, elevated expression of JAG2 was associated with reduced metastasis-free survival in three cohorts of breast cancer patients, suggesting that activation of Notch signaling confers breast cancer cells the ability to form bone metastases (91).

Osteoblastic cells regulate the hematopoietic stem cell niche and influence stem cell function through the activation of Notch (92). Although defective Notch activation can lead to a myeloproliferative disease in the mouse, hematological malignancies have been associated with the constitutive activation of NOTCH1 and NOTCH2 in humans (93). Activating mutations of NOTCH1 leading to the expression of a truncated protein are present in over $50 \%$ of T-cell acute lymphoblastic leukemia $(94,95)$. Patients with acute lymphoblastic leukemia may present with osteopenia and vertebral fractures and the prevalence of fractures in newly diagnosed children is $\sim 16 \%$ (96). Rarely, osteolytic lesions and hypercalcemia have been reported (97). Gain-of-function mutations of $\mathrm{NOTCH} 2$ were found in a subset of patients with large B-cell lymphoma, but their association with specific skeletal disorders is not known (98).

\section{Conclusions}

Genetic mutations causing either gain- or lossof-function of various components of the Notch signaling pathway are associated with diverse skeletal disorders and demonstrate that NOTCH is critical for human skeletal development and homeostasis. Findings in human diseases are consistent with results from numerous studies in mice and selected vertebrate model organisms, confirming that Notch signaling regulates skeletogenesis. Gain-of-function mutations of Notch lead to bone loss, and this is in agreement with the inhibitory effects of Notch on osteoblastogenesis, and with the stimulatory action of Notch2 on osteoclastogenesis. Various modalities to control Notch signaling have been reported, including the use of antibodies to the Notch extracellular domain or to its ligands, and the use of cell membrane permeable peptides that interfere with the formation of the Notch transcriptional complex, such as soluble MAML peptides $(99,100)$. However, reduced NOTCH signaling can result in the development of vascular tumors (101). There is strong evidence indicating that activation of $\mathrm{NOTCH} 2$ signaling causes HCS, and NOTCH2 could be a potential target for the treatment of this disease. However, for therapy to succeed, it needs to inhibit NOTCH2 activity specifically in affected tissues. Induction of NOTCH signaling is a critical event in the development and invasiveness of osteosarcoma and metastatic potential of carcinoma of the breast. NOTCH signaling could be targeted for the treatment of selected skeletal malignancies, but results from necessary clinical trials to establish the safety and efficacy of this approach are lacking. Targeting of NOTCH signaling in skeletal diseases associated with the loss of NOTCH activity would be even more problematic. Although strategies to activate Notch signaling were reported in a preclinical study, such approaches may result in serious complications due to the potential arrest of cell differentiation (102).

In conclusion, NOTCH signaling is required for skeletal development and bone homeostasis and gainand loss-of-function mutations in genes that regulate 
the NOTCH signaling pathway are uncommon but cause severe skeletal disorders.

\section{Declaration of interest}

The authors declare that there is no conflict of interest that could be perceived as prejudicing the impartiality of the review reported.

\section{Funding}

This work was supported by grant DK045227 (E Canalis) from the National Institute of Diabetes, Digestive and Kidney Diseases and by Research Fellowship 5371 from the Arthritis Foundation (S Zanotti).

\section{References}

1 Santagati F \& Rijli FM. Cranial neural crest and the building of the vertebrate head. Nature Reviews. Neuroscience 20034 806-818. (doi:10.1038/nrn1221)

2 Wellik DM. Hox patterning of the vertebrate axial skeleton. Developmental Dynamics 2007236 2454-2463. (doi:10.1002/ dvdy.21286)

3 Olsen BR, Reginato AM \& Wang W. Bone development. Annual Review of Cell and Developmental Biology 200016 191-220. (doi:10.1146/annurev.cellbio.16.1.191)

4 Bianco P \& Gehron RP. Marrow stromal stem cells. Journal of Clinical Investigation $2000 \mathbf{1 0 5}$ 1663-1668. (doi:10.1172/ JCI10413)

5 Canalis E. The fate of circulating osteoblasts. New England Journal of Medicine 2005352 2014-2016. (doi:10.1056/ NEJMe058080)

6 Park D, Spencer JA, Koh BI, Kobayashi T, Fujisaki J, Clemens TL, Lin CP, Kronenberg HM \& Scadden DT. Endogenous bone marrow MSCs are dynamic, fate-restricted participants in bone maintenance and regeneration. Cell Stem Cell $201210259-272$. (doi:10.1016/j.stem.2012.02.003)

7 Aarden EM, Burger EH \& Nijweide PJ. Function of osteocytes in bone. Journal of Cellular Biochemistry 199455 287-299. (doi:10.1002/jcb.240550304)

8 Bonewald LF. The amazing osteocyte. Journal of Bone and Mineral Research 201126 229-238. (doi:10.1002/jbmr.320)

9 Teitelbaum SL. Osteoclasts: what do they do and how do they do it? American Journal of Pathology 2007170 427-435. (doi:10.2353/ajpath.2007.060834)

10 Canalis E, Giustina A \& Bilezikian JP. Mechanisms of anabolic therapies for osteoporosis. New England Journal of Medicine 2007 357 905-916. (doi:10.1056/NEJMra067395)

11 Zanotti S \& Canalis E. Notch and the skeleton. Molecular and Cellular Biology 201030 886-896. (doi:10.1128/MCB. 01285-09)

12 Zanotti S \& Canalis E. Notch regulation of bone development and remodeling and related skeletal disorders. Calcified Tissue International 201290 69-75. (doi:10.1007/s00223-011-9541-x)

13 Fortini ME. Notch signaling: the core pathway and its posttranslational regulation. Developmental Cell 200916 633-647. (doi:10.1016/j.devcel.2009.03.010)

14 Iso T, Kedes L \& Hamamori Y. HES and ERP families: multiple effectors of the Notch signaling pathway. Journal of Cellular Physiology 2003 194 237-255. (doi:10.1002/jcp.10208)

15 Kopan R \& Ilagan MX. The canonical Notch signaling pathway: unfolding the activation mechanism. Cell 2009137 216-233. (doi:10.1016/j.cell.2009.03.045)

16 Kageyama R, Masamizu Y \& Niwa Y. Oscillator mechanism of Notch pathway in the segmentation clock. Developmental Dynamics 2007236 1403-1409. (doi:10.1002/dvdy.21114)
17 Saga Y. The mechanism of somite formation in mice. Current Opinion in Genetics \& Development 201222 331-338. (doi:10.1016/j.gde.2012.05.004)

18 Francis JC, Radtke F \& Logan MP. Notch1 signals through Jagged 2 to regulate apoptosis in the apical ectodermal ridge of the developing limb bud. Developmental Dynamics 2005234 1006-1015. (doi:10.1002/dvdy.20590)

19 Hilton MJ, Tu X, Wu X, Bai S, Zhao H, Kobayashi T, Kronenberg HM, Teitelbaum SL, Ross FP, Kopan R et al. Notch signaling maintains bone marrow mesenchymal progenitors by suppressing osteoblast differentiation. Nature Medicine $2008 \mathbf{1 4}$ 306-314. (doi:10.1038/nm1716)

20 Dong Y, Jesse AM, Kohn A, Gunnell LM, Honjo T, Zuscik MJ, O'Keefe RJ \& Hilton MJ. RBPjк-dependent Notch signaling regulates mesenchymal progenitor cell proliferation and differentiation during skeletal development. Development 2010137 1461-1471. (doi:10.1242/dev.042911)

21 Zanotti S, Smerdel-Ramoya A \& Canalis E. Hairy and enhancer of split (HES) 1 is a determinant of bone mass. Journal of Biological Chemistry $2011 \mathbf{2 8 6}$ 2648-2657. (doi:10.1074/jbc.M110. 183038)

22 Mead TJ \& Yutzey KE. Notch pathway regulation of chondrocyte differentiation and proliferation during appendicular and axial skeleton development. PNAS $2009 \mathbf{1 0 6} 14420-14425$. (doi:10.1073/pnas.0902306106)

23 Kohn A, Dong Y, Mirando AJ, Jesse AM, Honjo T, Zuscik MJ, O’Keefe RJ \& Hilton MJ. Cartilage-specific RBPjк-dependent and -independent Notch signals regulate cartilage and bone development. Development 2012139 1198-1212. (doi:10.1242/dev. 070649)

24 Chen S, Tao J, Bae Y, Jiang MM, Bertin T, Chen Y, Yang T \& Lee B. Notch gain of function inhibits chondrocyte differentiation via Rbpj-dependent suppression of Sox9. Journal of Bone and Mineral Research 201328 649-659. (doi:10.1002/jbmr.1770)

25 Zanotti S \& Canalis E. Notch suppresses nuclear factor of activated T cells (Nfat) transactivation and Nfatc 1 expression in chondrocytes. Endocrinology 2013154 762-772. (doi:10.1210/ en.2012-1925)

26 Engin F, Yao Z, Yang T, Zhou G, Bertin T, Jiang MM, Chen Y, Wang L, Zheng $\mathrm{H}$, Sutton RE et al. Dimorphic effects of Notch signaling in bone homeostasis. Nature Medicine 200814 299-305. (doi:10.1038/nm1712)

27 Zanotti S, Smerdel-Ramoya A, Stadmeyer L, Durant D, Radtke F \& Canalis E. Notch inhibits osteoblast differentiation and causes osteopenia. Endocrinology 2008149 3890-3899. (doi:10.1210/ en.2008-0140)

28 Tao J, Chen S, Yang T, Dawson B, Munivez E, Bertin T \& Lee B. Osteosclerosis owing to Notch gain of function is solely Rbpj-dependent. Journal of Bone and Mineral Research 201025 2175-2183. (doi:10.1002/jbmr.115)

29 Canalis E, Parker K, Feng JQ \& Zanotti S. Osteoblast lineagespecific effects of Notch activation in the skeleton. Endocrinology 2013154 623-634. (doi:10.1210/en.2012-1732)

30 Yamada T, Yamazaki H, Yamane T, Yoshino M, Okuyama H, Tsuneto M, Kurino T, Hayashi S \& Sakano S. Regulation of osteoclast development by Notch signaling directed to osteoclast precursors and through stromal cells. Blood 2003 101 2227-2234. (doi:10.1182/blood-2002-06-1740)

31 Bai S, Kopan R, Zou W, Hilton MJ, Ong CT, Long F, Ross FP \& Teitelbaum SL. NOTCH1 regulates osteoclastogenesis directly in osteoclast precursors and indirectly via osteoblast lineage cells. Journal of Biological Chemistry $2008 \mathbf{2 8 3} 6509-6518$. (doi:10.1074/jbc.M707000200)

32 Fukushima H, Nakao A, Okamoto F, Shin M, Kajiya H, Sakano S, Bigas A, Jimi E \& Okabe K. The association of Notch2 and NF- $\kappa$ B accelerates RANKL-induced osteoclastogenesis. Molecular and Cellular Biology 200828 6402-6412. (doi:10.1128/MCB. 00299-08)

33 Gridley T. Notch signaling and inherited disease syndromes. Human Molecular Genetics 200312 R9-R13. (doi:10.1093/hmg/ ddg052) 
34 Turnpenny PD, Alman B, Cornier AS, Giampietro PF, Offiah A, Tassy O, Pourquie O, Kusumi K \& Dunwoodie S. Abnormal vertebral segmentation and the Notch signaling pathway in man. Developmental Dynamics 2007236 1456-1474. (doi:10.1002/ dvdy.21182)

35 Gucev ZS, Tasic V, Pop-Jordanova N, Sparrow DB, Dunwoodie SL, Ellard S, Young E \& Turnpenny PD. Autosomal dominant spondylocostal dysostosis in three generations of a Macedonian family: negative mutation analysis of DLL3, MESP2, HES7, and LFNG. American Journal of Medical Genetics. Part A 2010 152A 1378-1382.

36 Kusumi K, Sun ES, Kerrebrock AW, Bronson RT, Chi DC, Bulotsky MS, Spencer JB, Birren BW, Frankel WN \& Lander ES. The mouse pudgy mutation disrupts delta homologue Dll3 and initiation of early somite boundaries. Nature Genetics 199819 274-278. (doi:10.1038/961)

37 Bulman MP, Kusumi K, Frayling TM, McKeown C, Garrett C, Lander ES, Krumlauf R, Hattersley AT, Ellard S \& Turnpenny PD. Mutations in the human delta homologue, DLL3, cause axial skeletal defects in spondylocostal dysostosis. Nature Genetics 200024 438-441. (doi:10.1038/74307)

38 Dunwoodie SL, Clements M, Sparrow DB, Sa X, Conlon RA \& Beddington RS. Axial skeletal defects caused by mutation in the spondylocostal dysplasia/pudgy gene Dll3 are associated with disruption of the segmentation clock within the presomitic mesoderm. Development 2002129 1795-1806.

39 Wang CH, Lin WD, Bau DT, Chou IC \& Tsai FJ. Genetic and clinical profiles of spondylocostal dysostosis patients in Taiwan. American Journal of Medical Genetics. Part A 2011 155A 3132-3135. (doi:10.1002/ajmg.a.34301)

40 Saga Y, Hata N, Koseki H \& Taketo MM. Mesp2: a novel mouse gene expressed in the presegmented mesoderm and essential for segmentation initiation. Genes and Development $1997 \mathbf{1 1}$ 1827-1839. (doi:10.1101/gad.11.14.1827)

41 Whittock NV, Sparrow DB, Wouters MA, Sillence D, Ellard S, Dunwoodie SL \& Turnpenny PD. Mutated MESP2 causes spondylocostal dysostosis in humans. American Journal of Human Genetics 200474 1249-1254. (doi:10.1086/421053)

42 Cornier AS, Staehling-Hampton K, Delventhal KM, Saga Y, Caubet JF, Sasaki N, Ellard S, Young E, Ramirez N, Carlo SE et al. Mutations in the MESP2 gene cause spondylothoracic dysostosis/Jarcho-Levin syndrome. American Journal of Human Genetics 200882 1334-1341. (doi:10.1016/j.ajhg.2008.04.014)

43 Stanley P. Regulation of Notch signaling by glycosylation. Current Opinion in Structural Biology 2007 17 530-535. (doi:10.1016/ j.sbi.2007.09.007)

44 Bessho Y, Sakata R, Komatsu S, Shiota K, Yamada S \& Kageyama R. Dynamic expression and essential functions of Hes7 in somite segmentation. Genes and Development 200115 2642-2647. (doi:10.1101/gad.930601)

45 Okubo Y, Sugawara T, Abe-Koduka N, Kanno J, Kimura A \& Saga Y. Lfng regulates the synchronized oscillation of the mouse segmentation clock via trans-repression of Notch signalling. Nature Communications 20123 1141. (doi:10.1038/ ncomms2133)

46 Sparrow DB, Chapman G, Wouters MA, Whittock NV, Ellard S, Fatkin D, Turnpenny PD, Kusumi K, Sillence D \& Dunwoodie SL. Mutation of the LUNATIC FRINGE gene in humans causes spondylocostal dysostosis with a severe vertebral phenotype. American Journal of Human Genetics 200678 28-37. (doi:10.1086/498879)

47 Sparrow DB, Guillen-Navarro E, Fatkin D \& Dunwoodie SL. Mutation of Hairy-and-enhancer-of-split-7 in humans causes spondylocostal dysostosis. Human Molecular Genetics 200817 3761-3766. (doi:10.1093/hmg/ddn272)

48 Dunwoodie SL. Mutation of the fucose-specific $\beta 1,3 \mathrm{~N}$-acetylglucosaminyltransferase LFNG results in abnormal formation of the spine. Biochimica et Biophysica Acta 20091792 100-111. (doi:10.1016/j.bbadis.2008.11.003)

49 Sparrow DB, Sillence D, Wouters MA, Turnpenny PD \& Dunwoodie SL. Two novel missense mutations in Hairy- and-enhancer-of-split-7 in a family with spondylocostal dysostosis. European Journal of Human Genetics 201018 674-679. (doi:10.1038/ejhg.2009.241)

50 Temtamy SA \& Aglan MS. Brachydactyly. Orphanet Journal of Rare Diseases 20083 15. (doi:10.1186/1750-1172-3-15)

51 Sidow A, Bulotsky MS, Kerrebrock AW, Bronson RT, Daly MJ, Reeve MP, Hawkins TL, Birren BW, Jaenisch R \& Lander ES. Serrate 2 is disrupted in the mouse limb-development mutant syndactylism. Nature $1997 \mathbf{3 8 9}$ 722-725. (doi:10.1038/ 39587)

52 Jiang R, Lan Y, Chapman HD, Shawber C, Norton CR, Serreze DV, Weinmaster G \& Gridley T. Defects in limb, craniofacial, and thymic development in Jagged2 mutant mice. Genes and Development 199812 1046-1057. (doi:10.1101/gad.12.7. 1046)

53 Tian J, Ling L, Shboul M, Lee H, O'Connor B, Merriman B, Nelson SF, Cool S, Ababneh OH, Al-Hadidy A et al. Loss of CHSY1, a secreted FRINGE enzyme, causes syndromic brachydactyly in humans via increased NOTCH signaling. American Journal of Human Genetics 201087 768-778. (doi:10.1016/j.ajhg.2010. 11.005)

54 Wilson DG, Phamluong K, Lin WY, Barck K, Carano RA, Diehl L, Peterson AS, Martin F \& Solloway MJ. Chondroitin sulfate synthase 1 (Chsy1) is required for bone development and digit patterning. Developmental Biology 2012363 413-425. (doi:10.1016/j.ydbio.2012.01.005)

55 Alagille D, Estrada A, Hadchouel M, Gautier M, Odievre M \& Dommergues JP. Syndromic paucity of interlobular bile ducts (Alagille syndrome or arteriohepatic dysplasia): review of 80 cases. Journal of Pediatrics 1987110 195-200. (doi:10.1016/ SO022-3476(87)80153-1)

56 Emerick KM, Rand EB, Goldmuntz E, Krantz ID, Spinner NB \& Piccoli DA. Features of Alagille syndrome in 92 patients: frequency and relation to prognosis. Hepatology 199929 822-829. (doi:10.1002/hep.510290331)

57 Crosnier C, Driancourt C, Raynaud N, Dhorne-Pollet S, Pollet N, Bernard O, Hadchouel M \& Meunier-Rotival M. Mutations in JAGGED1 gene are predominantly sporadic in Alagille syndrome. Gastroenterology 1999116 1141-1148. (doi:10.1016/SO0165085(99)70017-X)

58 Morrissette JD, Colliton RP \& Spinner NB. Defective intracellular transport and processing of JAG1 missense mutations in Alagille syndrome. Human Molecular Genetics $2001 \quad \mathbf{1 0}$ 405-413. (doi:10.1093/hmg/10.4.405)

59 Bauer RC, Laney AO, Smith R, Gerfen J, Morrissette JJ, Woyciechowski S, Garbarini J, Loomes KM, Krantz ID, Urban Z et al. Jagged1 (JAG1) mutations in patients with Tetralogy of Fallot or pulmonic stenosis. Human Mutation 201031 594-601. (doi:10.1002/humu.21231)

60 McDaniell R, Warthen DM, Sanchez-Lara PA, Pai A, Krantz ID, Piccoli DA \& Spinner NB. NOTCH2 mutations cause Alagille syndrome, a heterogeneous disorder of the Notch signaling pathway. American Journal of Human Genetics 2006 79 169-173. (doi:10.1086/505332)

61 Kamath BM, Bauer RC, Loomes KM, Chao G, Gerfen J, Hutchinson A, Hardikar W, Hirschfield G, Jara P, Krantz ID et al. NOTCH2 mutations in Alagille syndrome. Journal of Medical Genetics 201249 138-144. (doi:10.1136/jmedgenet-2011100544)

62 McCright B, Lozier J \& Gridley T. A mouse model of Alagille syndrome: Notch2 as a genetic modifier of Jag1 haploinsufficiency. Development 2002129 1075-1082.

63 Humphreys R, Zheng W, Prince LS, Qu X, Brown C, Loomes K, Huppert SS, Baldwin S \& Goudy S. Cranial neural crest ablation of Jagged 1 recapitulates the craniofacial phenotype of Alagille syndrome patients. Human Molecular Genetics 201221 1374-1383. (doi:10.1093/hmg/ddr575)

64 Hajdu N \& Kauntze R. Cranio-skeletal dysplasia. British Journal of Radiology $1948 \mathbf{2 1}$ 42-48. (doi:10.1259/0007-1285-21241-42) 
65 Cheney WD. Acro-osteolysis. American Journal of Roentgenology, Radium Therapy, and Nuclear Medicine 196594 595-607.

66 Silverman FN, Dorst JP \& Hajdu N. Acroosteolysis (HajduCheney syndrome). Birth Defects Original Article Series 197410 106-123.

67 Currarino G. Hajdu-Cheney syndrome associated with serpentine fibulae and polycystic kidney disease. Pediatric Radiology 200939 47-52. (doi:10.1007/s00247-008-0992-9)

68 Gray MJ, Kim CA, Bertola DR, Arantes PR, Stewart H, Simpson MA, Irving MD \& Robertson SP. Serpentine fibula polycystic kidney syndrome is part of the phenotypic spectrum of Hajdu-Cheney syndrome. European Journal of Human Genetics 201220 122-124. (doi:10.1038/ejhg.2011.125)

69 Isidor B, Lindenbaum P, Pichon O, Bezieau S, Dina C, Jacquemont S, Martin-Coignard D, Thauvin-Robinet C, Le MM, Mandel JL et al. Truncating mutations in the last exon of NOTCH2 cause a rare skeletal disorder with osteoporosis. Nature Genetics 201143 306-308. (doi:10.1038/ng.778)

70 Simpson MA, Irving MD, Asilmaz E, Gray MJ, Dafou D, Elmslie FV, Mansour S, Holder SE, Brain CE, Burton BK et al. Mutations in NOTCH2 cause Hajdu-Cheney syndrome, a disorder of severe and progressive bone loss. Nature Genetics 201143 303-305. (doi:10.1038/ng.779)

71 Majewski J, Schwartzentruber JA, Caqueret A, Patry L, Marcadier J, Fryns JP, Boycott KM, Ste-Marie LG, McKiernan FE, Marik I et al. Mutations in NOTCH2 in families with HajduCheney syndrome. Human Mutation 201132 1114-1117. (doi:10.1002/humu.21546)

72 Nunziata V, di Giovanni G, Ballanti P \& Bonucci E. High turnover osteoporosis in acro-osteolysis (Hajdu-Cheney syndrome). Journal of Endocrinological Investigation 199013 251-255.

73 Udell J, Schumacher HR Jr, Kaplan F \& Fallon MD. Idiopathic familial acroosteolysis: histomorphometric study of bone and literature review of the Hajdu-Cheney syndrome. Arthritis and Rheumatism 198629 1032-1038. (doi:10.1002/art. 1780290815)

74 Elias AN, Pinals RS, Anderson HC, Gould LV \& Streeten DH. Hereditary osteodysplasia with acro-osteolysis (the Hajdu-Cheney syndrome). American Journal of Medicine 197865 627-636. (doi:10.1016/0002-9343(78)90851-3)

75 Blumenauer BT, Cranney AB \& Goldstein R. Acro-osteolysis and osteoporosis as manifestations of the Hajdu-Cheney syndrome. Clinical and Experimental Rheumatology 200220 574-575.

76 Brown DM, Bradford DS, Gorlin RJ, Desnick RJ, Langer LO, Jowsey J \& Sauk JJ. The acro-osteolysis syndrome: morphologic and biochemical studies. Journal of Pediatrics $1976 \mathbf{8 8} 573-580$. (doi:10.1016/S0022-3476(76)80009-1)

77 Avela K, Valanne L, Helenius I \& Makitie O. Hajdu-Cheney syndrome with severe dural ectasia. American Journal of Medical Genetics. Part A 2011 155A 595-598. (doi:10.1002/ajmg.a. 33510)

78 McKiernan FE. Integrated anti-remodeling and anabolic therapy for the osteoporosis of Hajdu-Cheney syndrome: 2-year followup. Osteoporosis International 200819 379-380. (doi:10.1007/ s00198-007-0461-6)

79 Galli-Tsinopoulou A, Kyrgios I, Giza S, Giannopoulou EM, Maggana I \& Laliotis N. Two-year cyclic infusion of pamidronate improves bone mass density and eliminates risk of fractures in a girl with osteoporosis due to Hajdu-Cheney syndrome. Minerva Endocrinologica 201237 283-289.

80 Isidor B, Le MM, Exner GU, Pichon O, Thierry G, GuiochonMantel A, David A, Cormier-Daire V \& Le CC. Serpentine fibulapolycystic kidney syndrome caused by truncating mutations in NOTCH2. Human Mutation 201132 1239-1242. (doi:10.1002/ humu.21563)

81 Majewski F, Enders H, Ranke MB \& Voit T. Serpentine fibulapolycystic kidney syndrome and Melnick-Needles syndrome are different disorders. European Journal of Pediatrics 1993152 916-921. (doi:10.1007/BF01957530)
82 Fisher E. A step forward on the path towards understanding osteoporosis. Clinical Genetics 201180 136-137. (doi:10.1111/ j.1399-0004.2011.01702.x)

83 Richards JB, Kavvoura FK, Rivadeneira F, Styrkarsdottir U, Estrada K, Halldorsson BV, Hsu YH, Zillikens MC, Wilson SG, Mullin BH et al. Collaborative meta-analysis: associations of 150 candidate genes with osteoporosis and osteoporotic fracture. Annals of Internal Medicine 2009151 528-537. (doi:10.7326/ 0003-4819-151-8-200910200-00006)

84 Kung AW, Xiao SM, Cherny S, Li GH, Gao Y, Tso G, Lau KS, Luk KD, Liu JM, Cui B et al. Association of JAG1 with bone mineral density and osteoporotic fractures: a genome-wide association study and follow-up replication studies. American Journal of Human Genetics $2010 \mathbf{8 6}$ 229-239. (doi:10.1016/ j.ajhg.2009.12.014)

85 Leong KG \& Karsan A. Recent insights into the role of Notch signaling in tumorigenesis. Blood $2006 \mathbf{1 0 7} 2223-2233$. (doi:10.1182/blood-2005-08-3329)

86 Engin F, Bertin T, Ma O, Jiang MM, Wang L, Sutton RE, Donehower LA \& Lee B. Notch signaling contributes to the pathogenesis of human osteosarcomas. Human Molecular Genetics 200918 1464-1470. (doi:10.1093/hmg/ddp057)

87 Zhang P, Yang Y, Zweidler-McKay PA \& Hughes DP. Critical role of Notch signaling in osteosarcoma invasion and metastasis. Clinical Cancer Research 200814 2962-2969. (doi:10.1158/ 1078-0432.CCR-07-1992)

88 Kolb EA, Gorlick R, Keir ST, Maris JM, Lock R, Carol H, Kurmasheva RT, Reynolds CP, Kang MH, Wu J et al. Initial testing (stage 1) by the pediatric preclinical testing program of R04929097, a $\gamma$-secretase inhibitor targeting Notch signaling. Pediatric Blood \& Cancer 201258 815-818. (doi:10.1002/pbc. 23290)

89 Zhang Z, Wang H, Ikeda S, Fahey F, Bielenberg D, Smits P \& Hauschka PV. Notch3 in human breast cancer cell lines regulates osteoblast-cancer cell interactions and osteolytic bone metastasis. American Journal of Pathology 2010177 1459-1469. (doi:10.2353/ajpath.2010.090476)

90 Sethi N, Dai X, Winter CG \& Kang Y. Tumor-derived JAGGED1 promotes osteolytic bone metastasis of breast cancer by engaging Notch signaling in bone cells. Cancer Cell 201119 192-205. (doi:10.1016/j.ccr.2010.12.022)

91 Xing F, Okuda H, Watabe M, Kobayashi A, Pai SK, Liu W, Pandey PR, Fukuda K, Hirota S, Sugai T et al. Hypoxia-induced Jagged2 promotes breast cancer metastasis and self-renewal of cancer stem-like cells. Oncogene 201130 4075-4086. (doi:10.1038/onc.2011.122)

92 Calvi LM, Adams GB, Weibrecht KW, Weber JM, Olson DP, Knight MC, Martin RP, Schipani E, Divieti P, Bringhurst FR et al. Osteoblastic cells regulate the haematopoietic stem cell niche. Nature 2003425 841-846. (doi:10.1038/nature02040)

93 Kim YW, Koo BK, Jeong HW, Yoon MJ, Song R, Shin J, Jeong DC, Kim SH \& Kong YY. Defective Notch activation in microenvironment leads to myeloproliferative disease. Blood 2008 112 4628-4638. (doi:10.1182/blood-2008-03-148999)

94 Van VP \& Ferrando A. The molecular basis of T cell acute lymphoblastic leukemia. Journal of Clinical Investigation 2012 122 3398-3406. (doi:10.1172/JCI61269)

95 Weng AP, Ferrando AA, Lee W, Morris JP, Silverman LB, Sanchez-Irizarry C, Blacklow SC, Look AT \& Aster JC. Activating mutations of NOTCH1 in human T cell acute lymphoblastic leukemia. Science 2004306 269-271. (doi:10.1126/science. 1102160)

96 Halton J, Gaboury I, Grant R, Alos N, Cummings EA, Matzinger M, Shenouda N, Lentle B, Abish S, Atkinson S et al. Advanced vertebral fracture among newly diagnosed children with acute lymphoblastic leukemia: results of the Canadian Steroid-Associated Osteoporosis in the Pediatric Population (STOPP) research program. Journal of Bone and Mineral Research 200924 1326-1334. (doi:10.1359/jbmr.090202) 
97 Soni PN. Hypercalcaemia and multiple osteolytic lesions in childhood acute lymphoblastic leukaemia. Postgraduate Medical Journal 199369 483-485. (doi:10.1136/pgmj.69.812.483)

98 Lee SY, Kumano K, Nakazaki K, Sanada M, Matsumoto A, Yamamoto G, Nannya Y, Suzuki R, Ota S, Ota Y et al. Gain-of-function mutations and copy number increases of Notch2 in diffuse large B-cell lymphoma. Cancer Science 2009 100 920-926. (doi:10.1111/j.1349-7006.2009.01130.x)

99 Moellering RE, Cornejo M, Davis TN, Del Bianco C, Aster JC, Blacklow SC, Kung AL, Gilliland DG, Verdine GL \& Bradner JE. Direct inhibition of the NOTCH transcription factor complex. Nature 2009462 182-188. (doi:10.1038/nature08543)

100 Ryeom SW. The cautionary tale of side effects of chronic Notch1 inhibition. Journal of Clinical Investigation 2011121 508-509. (doi:10.1172/JCI45976)
101 Liu Z, Turkoz A, Jackson EN, Corbo JC, Engelbach JA, Garbow JR, Piwnica-Worms DR \& Kopan R. Notch1 loss of heterozygosity causes vascular tumors and lethal hemorrhage in mice. Journal of Clinical Investigation $2011 \mathbf{1 2 1}$ 800-808. (doi:10.1172/ JCI43114)

102 Kannan S, Sutphin RM, Hall MG, Golfman LS, Fang W, Nolo RM, Akers LJ, Hammitt RA, McMurray JS, Kornblau SM et al. Notch activation inhibits AML growth and survival: a potential therapeutic approach. Journal of Experimental Medicine 2013 210 321-337. (doi:10.1084/jem.20121527)

Received 4 February 2013

Revised version received 8 March 2013

Accepted 3 April 2013 